\title{
Construction of National Defense Patent Value Evaluation Index System
}

\author{
Zhu Wenbo ${ }^{1}$ Zhang Guojie $^{2, *}$ Zhang Zhigang $^{3}$ \\ ${ }^{1,2,3}$ PLA Army Logistics Academy \\ *Corresponding author. Email: zhuwenbolynn@163.com
}

\begin{abstract}
Based on factors that affect the value of national defense patents, this paper constructs a national defense patent value evaluation index system consisting of six root indexes including military indexes, legal indexes, economic indexes, technical indexes, risk indexes and social indexes, as well as its sub-indexes. It also introduces how to use the analytic hierarchy process to determine the weight of each index, which provides a reliable technical path for the evaluation of national defense patent value.
\end{abstract}

Keywords: national defense patent, value evaluation, index system

\section{INTRODUCTION}

The construction of the national defense patent value evaluation index system refers to the whole process of summarizing the factors that affect the value of national defense patents and determining their respective influence degree when evaluating their value. As a special form of patents, national defense patents are affected by more complicated factors than ordinary patents. Only by adhering to scientific and effective guidelines, adopting rigorous and advanced research methods, decompositions and integrates various indicators from different perspectives and levels, and building a practical and reasonable index system for evaluating the value of national defense patents, can the actual value of national defense patents be objectively and accurately assessed [1].

\section{PRINCIPLES OF DESIGNING NATIONAL DEFENSE PATENT VALUE EVALUATION INDEX}

To construct an index system for evaluating the value of national defense patents, the primary task is to clarify the principles for establishing the index system. First analyze the characteristics of the national defense patents to be assessed, and then set up indicators for their characteristics, and then summarize the principles of the establishment of the indicator system.

\subsection{Principle of Scientific Rationality}

The various indicators in the national defense patent value evaluation index system represent various factors affecting the value of related national defense patents. For the evaluation of national defense patents, such factors are numerous and complicated, and must be scientifically abstracted, rationally selected and discarded. To ensure the usefulness of the index system, it is necessary to adhere to the principle of scientific rationality when selecting indicators, fully consider the characteristics of the national defense patent to be assessed, determine its reasonable influencing factors, and conduct scientific integration, so as to refine the representative categories and integrate them into the system in an orderly way.

\subsection{Principle of Objectivity and Fairness}

The value of national defense patent directly restricts its circulation and operation. Therefore, establishing the credibility of the evaluation conclusion of national defense patent value to be evaluated is the most important task of national defense patent value evaluation and pricing. When designing a national defense patent value evaluation index system, it is necessary to make the indicators contained in it to objectively and fairly reflect the value influencing factors of the national defense patent to be assessed. There should be no arbitrary setting of indicators, such as different indicators with the same factors, different 
indicators with the same meaning, and different standards with the same meaning [2]. Therefore, in the construction of the relevant index system, it is necessary to adhere to the objectification of the index selection, the unification of the standard quantization and the normalization of the weight setting, so that different indexes in the index system can be added, comparable, and convertible.

\subsection{Principle of Economy and Practicality}

National defense patent value evaluation and pricing is a complex activity. The establishment of its value evaluation index requires a lot of theoretical research and practical research. It is constructed in a targeted manner based on the many characteristics of the defence patent to be assessed, and the meaning of each index in this index system must be clear, the data must be accurate, calculation must be accurate. Therefore, when designing a national defense patent value evaluation index system, try to select indicators that are easy to obtain, easy to measure, easy to understand, and easy to evaluate, so as to minimize the difficulty and cost of national defense patent value evaluation while ensuring the quality of evaluation, improve its practicality and applicability, and highlight the principle of economic and practical application.

\subsection{Principles of Highlighting Key Points}

The national defense patent value evaluation index system involves many indexes and levels. Therefore, in the design and selection of specific indicators, it is necessary to make some choices and highlight the key points, so that the selected indicators can not only have a wide range of representativeness, but also not bogged down in tedious work. In addition, the level of the national defense patent value evaluation index system should be simplified and summarized as far as possible, so that the contributions of each index to the index system will not be eliminated due to their mutual influence, and make it easy to collect and sort out. Therefore, in the design of the index system, it is necessary to adhere to the principle of emphasis, and try to select the important indexes that have the greatest impact on the value of national defense patents, while the indexes with little impact can be combined or weakened.

\section{ESTABLISHMENT OF NATIONAL DEFENSE PATENT VALUE EVALUATION INDEX SYSTEM}

The national defense patent value evaluation index system is a comprehensive index system which includes many indexes and involves many levels. It is abstract based on many influencing factors. In general, the evaluation of the value of national defense patents mainly includes six factors including military, legal, economic, technological, risk, and social. On this basis, the evaluation indicators of national defense patent value can be divided into six categories, namely military indicators, legal indicators, economic indicators, technical indicators, risk indicators, and social indicators.

\subsection{Military Indicators}

\subsubsection{Safety environment indicators}

Safety environment indicators refer to the external and internal safety conditions of the country. Generally, the harsher the security environment, the higher the value of related defence patents.

\subsubsection{Arms race indicators}

Arms race indicators indicate that a country is caught up in an arms race. In general, in the early stage of the arms race, relevant national defense patents have high value, but once dragged into the mire of the arms race, some national defense patents will become worthless, or even have negative effect.

\subsubsection{Military demand indicators}

Military demand indicator refers to the demand for relevant national defense patents and the products they are applied to, which is proportional to the value of national defense patents.

\subsubsection{Tactical performance indicators:}

Tactical performance indicators refers to the degree to which the application of national defense patents can improve the tactical performance of relevant weapons and equipment, which is directly proportional to the value of national defense patents.

\subsection{Legal Indicators}

\subsubsection{Rights status indicators}

Rights status indicators include the index of the degree of property right integrity, the index of the scope of right protection and the index of the difficulty of judging infringement. The higher the degree of national defense patent property right integrity, the wider the scope of right protection and the lower the difficulty of infringement judgment, the higher its value.

\subsubsection{Legal status indicators}

The legal status indicators refer to the legal stage of the relevant national defense patent right. It generally goes through the national defense patent pre-application status, the national defense patent application status, the national defense patent grant status, and the defence 
patent litigation dispute status. In addition, national defense patent can also be classified into the state of national defense patent confidentiality and the state of national defense patent decryption. The value of the defense patent to be evaluated will generally increase with the extension of the patent stage, and may increase as the state of secrecy changes to the state of decryption.

\subsubsection{Protection intensity indicators}

The higher the protection intensity of the national defense patent to be evaluated is, the more guaranteed its value will be and the higher its evaluation value will be.

\subsubsection{Patent pool status indicators}

The more important the national defense patent is in the related patent pool and the more extensive its influence is in the patent family, the higher its value will be.

\subsubsection{Remaining life indicators}

The longer the remaining life of the national defense patent to be estimated, the higher its value.

\subsubsection{Tax rate indicators}

The lower the tax rate, the higher the value of national defense patents.

\subsection{Economic Indicators}

\subsubsection{Macro indicators}

The more favorable the relevant industrial policies are, the higher the value of national defense patents to be evaluated will be. In addition, the value of national defense patents is directly proportional to the price index and interest rate index, and inversely proportional to the inflation index.

\subsubsection{Cost indicators}

The larger the value of R\&D cost index, application and maintenance cost index, materialized labor consumption index, complex labor multiplier index, and opportunity cost index, the higher the cost of the national defense patent, and the higher its value.

\subsubsection{Profit indicators}

The use mode of national defense patent to be evaluated will directly restrict its value. For example, the value of the ownership is higher than the value of the right of use, and the value of the exclusive license is higher than the value of the ordinary license. In addition, the value of the national defense patent is directly proportional to the expected income index, the income period index and the share rate index, and inversely proportional to the discount rate index.

\subsubsection{Market indicators}

The more perfect the market, the lower the degree of competition, the more obvious the demand for national defense patents, the better the market prospect, and the lower the value of relevant patents, the higher the national defense patent value. In addition, the higher the market share and the larger the market capacity of the national defense patent, the greater its value will be.

\subsection{Technical Indicators}

\subsubsection{Technical field indicators}

The technical field indicators include the technical development stage indicators, the technical implementation difficulty indicators, the technical competition intensity indicators and the related technical field condition indicators. Generally speaking, the more compatible the national defense patent technology is with its technology development stage, the less difficult its technology implementation is, the less competitive its technology is, and the slower the related technology field is updated, the higher its value will be.

\subsubsection{Technical characteristic indicators}

The technical characteristic indicators include the index of technology leading degree, the index of technology defending ability and the index of technology innovation degree. The more advanced the national defense patent technology, the stronger the defence capability, and more innovative the national defense patented technology, the higher its value will be.

\subsubsection{Technical application indicators}

Technical application indicators include technical maturity indicators, technical application scope indicators, technical application conditions indicators and related technical complementarity indicators. The more mature the national defense patent technology to be evaluated, the wider the application scope, the more perfect the application conditions and the higher the complementary degree of related technologies, the higher its value will be.

\subsection{Risk Indicators}

The risk indicators involved in the defence patent value evaluation indicator system include military risk indicators, legal risk indicators, economic risk indicators, technical risk indicators, and management 
risk indicators, all of which are inversely proportional to the value of the defence patent to be evaluated. The technical risk indicators include technical rights risk indicators, technology transformation risk indicators, technology substitution risk indicators, and technology cooperation risk indicators [3]. In addition, economic risk indicators can be constructed from three levels: macro, meso, and micro. The macro level refers to macroeconomic risk indicators, the meso level refers to market risk indicators, and the micro level refers to financial risk indicators, all of which are inversely proportional to the value of national defense patent to be evaluated.

\subsection{Social Indicators}

\subsubsection{Social benefit indicators}

The greater the positive externality of the national defense patent to be evaluated, the higher the benefit to the society, then the higher its value.

\subsubsection{Public benefit indicators}

The greater the positive externality a national defense patent has to the public, the higher the benefits it brings to the public, and the more praised by the public, the higher its value.

\subsubsection{Environmental benefit indicators}

The greater the positive externality a national defense patent produces to the natural environment, the easier it is to protect the ecological environment, and the less damage it causes, the higher its value.

The national defense patent value evaluation index system is a multi-dimensional comprehensive evaluation system. The above is mainly to construct the national defense value evaluation index from the perspective of quantification. Taking military indicators, legal indicators, economic indicators, technical indicators, risk indicators, and social indicators as the root index layer, the lower and more lower layers include several sub-index layers respectively, thus constituting a relatively complete national defense patent value evaluation indicator System (as shown in Table 1).

Table 1 National defense patent value evaluation index system

\begin{tabular}{|c|c|c|c|c|c|}
\hline $\begin{array}{c}\text { Root } \\
\text { indicators }\end{array}$ & $\begin{array}{l}\text { Secondary } \\
\text { indicators }\end{array}$ & Tertiary indicators & $\begin{array}{c}\text { Root } \\
\text { indicators }\end{array}$ & $\begin{array}{l}\text { Secondary } \\
\text { indicators }\end{array}$ & Tertiary indicators \\
\hline \multirow{19}{*}{$\begin{array}{l}\text { Economic } \\
\text { indicators }\end{array}$} & \multirow{4}{*}{$\begin{array}{l}\text { Macroecon } \\
\text { omic } \\
\text { indicators }\end{array}$} & Industrial policy & \multirow{4}{*}{$\begin{array}{l}\text { Military } \\
\text { indicators }\end{array}$} & $\begin{array}{l}\text { Security } \\
\text { environment }\end{array}$ & \\
\hline & & Price Index & & Arms race & \\
\hline & & Inflation rate & & $\begin{array}{l}\text { Military } \\
\text { requirement }\end{array}$ & \\
\hline & & interest rate & & $\begin{array}{l}\text { Tactical } \\
\text { performance }\end{array}$ & \\
\hline & \multirow{5}{*}{$\begin{array}{l}\text { Cost } \\
\text { indicators }\end{array}$} & $\begin{array}{l}\text { Research and } \\
\text { development costs }\end{array}$ & \multirow{13}{*}{$\begin{array}{l}\text { Legal } \\
\text { indicators }\end{array}$} & \multirow{3}{*}{ Rights status } & Property integrity degree \\
\hline & & $\begin{array}{l}\text { Application and } \\
\text { maintenance cost }\end{array}$ & & & Scope of rights protection \\
\hline & & $\begin{array}{l}\text { Materialized labor } \\
\text { consumption index }\end{array}$ & & & $\begin{array}{l}\text { Difficulty of infringement } \\
\text { judgment }\end{array}$ \\
\hline & & $\begin{array}{l}\text { Complex labor } \\
\text { multiplication } \\
\text { coefficient }\end{array}$ & & \multirow{6}{*}{ Legal status } & $\begin{array}{l}\text { Status before defense patent } \\
\text { application }\end{array}$ \\
\hline & & Opportunity cost & & & $\begin{array}{l}\text { National defense patent } \\
\text { application status }\end{array}$ \\
\hline & \multirow{5}{*}{$\begin{array}{l}\text { Profit } \\
\text { indicators }\end{array}$} & expected profits & & & $\begin{array}{l}\text { National defense patent awarded } \\
\text { status }\end{array}$ \\
\hline & & Profit period & & & $\begin{array}{l}\text { National defense patent litigation } \\
\text { dispute status }\end{array}$ \\
\hline & & Discount rate & & & $\begin{array}{l}\text { National defense patent } \\
\text { confidentiality status }\end{array}$ \\
\hline & & Share rate & & & $\begin{array}{l}\text { National defense patent } \\
\text { decryption status }\end{array}$ \\
\hline & & Patent usage & & $\begin{array}{l}\text { Protection } \\
\text { intensity }\end{array}$ & \\
\hline & \multirow{5}{*}{$\begin{array}{l}\text { Market } \\
\text { indicators }\end{array}$} & Market sophistication & & Patent pool status & \\
\hline & & Market share & & Remaining life & \\
\hline & & Market competition & & Tax rate & \\
\hline & & $\begin{array}{l}\text { Market supply and } \\
\text { demand }\end{array}$ & \multirow{2}{*}{$\begin{array}{l}\text { Technical } \\
\text { indicators }\end{array}$} & \multirow{2}{*}{ Technical field } & Technology development stage \\
\hline & & Market capacity & & & $\begin{array}{l}\text { Technology implementation } \\
\text { difficulty }\end{array}$ \\
\hline
\end{tabular}




\begin{tabular}{|c|c|c|c|c|c|}
\hline & & \multirow{2}{*}{$\begin{array}{l}\text { Market prospect } \\
\text { Market value of related } \\
\text { patents }\end{array}$} & & \multirow{4}{*}{ Technical features } & \multirow{2}{*}{$\begin{array}{l}\text { Technology competition intensity } \\
\text { Related technical fields status }\end{array}$} \\
\hline & & & & & \\
\hline \multirow{10}{*}{$\begin{array}{l}\text { Risk } \\
\text { indicators }\end{array}$} & $\begin{array}{l}\text { Military } \\
\text { risk }\end{array}$ & & & & Technology leadership level \\
\hline & Legal risk & & & & Technical defense capability \\
\hline & & Macroeconomic risk & & & Technological innovation degree \\
\hline & Economic & Market risk & & \multirow{4}{*}{$\begin{array}{l}\text { Technology } \\
\text { application }\end{array}$} & Technology maturity level \\
\hline & & Financial risk & & & Technical application scope \\
\hline & \multirow{4}{*}{$\begin{array}{l}\text { Technical } \\
\text { risk }\end{array}$} & Technology rights risk & & & Technical application conditions \\
\hline & & $\begin{array}{l}\text { Technology } \\
\text { transformation risk }\end{array}$ & & & $\begin{array}{l}\text { Complementary degree of related } \\
\text { technologies }\end{array}$ \\
\hline & & $\begin{array}{l}\text { Technology substitution } \\
\text { risk }\end{array}$ & \multirow{3}{*}{$\begin{array}{l}\text { Social } \\
\text { indicators }\end{array}$} & Social benefits & \\
\hline & & $\begin{array}{l}\text { Technical coordination } \\
\text { risk }\end{array}$ & & Public benefit & \\
\hline & $\begin{array}{l}\text { Manage } \\
\text { risk }\end{array}$ & & & $\begin{array}{l}\text { Environmental } \\
\text { benefit }\end{array}$ & \\
\hline
\end{tabular}

\section{DETERMINATION OF THE WEIGHT} OF NATIONAL DEFENSE PATENT VALUE EVALUATION INDEX BASED ON ANALYTIC HIERARCHY PROCESS

In the national defense patent value evaluation index system, each evaluation index has a different degree of influence on the value of the national defense patent, so it is necessary to assign different weights to them. Generally speaking, index weighting methods are divided into subjective weighting methods and objective weighting methods, such as analytic hierarchy process, Delphi method and frequency statistics method, which belong to subjective weighting methods, while principal component analysis (PCA) and entropy method belong to objective weighting methods [4].

As a main subjective weighting method, Analytic Hierarchy Process can express and process people's subjective preferences in quantitative form, scientifically distinguish various influencing factors and assign their values to mathematical transformations, and then obtain reasonable weight values through consistency tests, thereby reducing the influence of subjective factors, and at the same time incorporating various indicators into different hierarchical structures, so it is more flexible and effective than other methods, and the conclusions are more credible [5]. It is particularly applicable to issues such as defense patent value evaluation that lack quantitative data and have strong policy implications, which can promote effective communication between the transferor and the transferee of the defense patent, and the licensor and the licensee. In this paper, the analytic hierarchy process (AHP) will be adopted to decompose the factors that affect the value of the national defense patent according to its characteristics. form indicators for the influencing factors. The national defense patent value evaluation index is constructed according to the influencing factors, and the hierarchy structure is formed according to the dominant relationship. Then the relative importance of the evaluation index of the same level is determined by the paired comparison method, and the weight of each indicator in the national defense patent value evaluation index system is finally determined.

\subsection{Establishment of a hierarchical structure}

Taking the impact of the technical indicators in the national defense patent value evaluation index system on the evaluation of national defense patents as an example, a hierarchical structure was established according to the interrelationship of the technical indicators. 


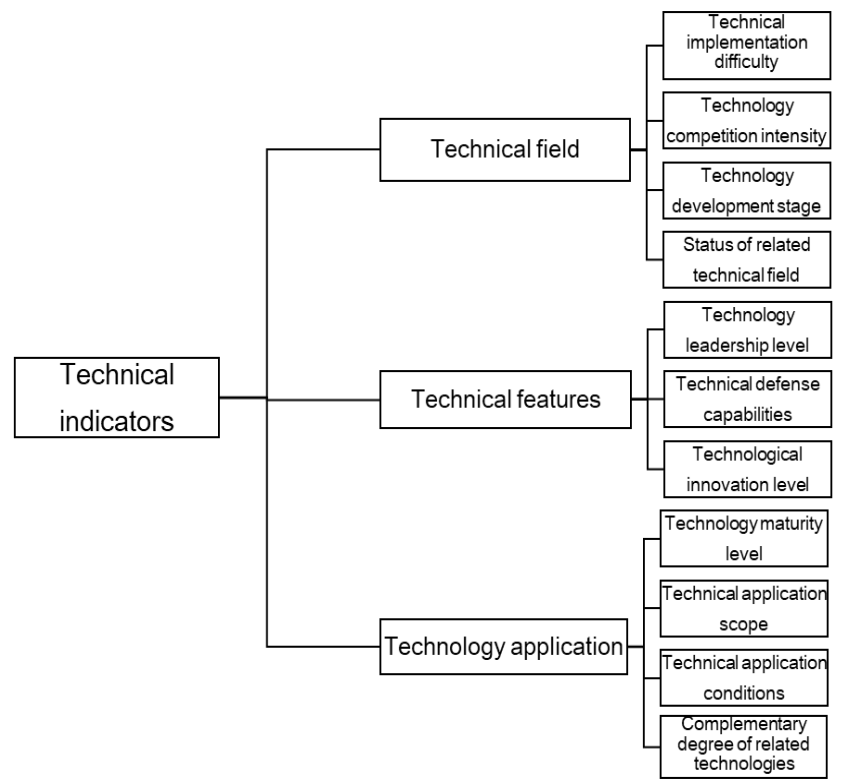

Figure 1 Technical index hierarchy chart of national defense patent value evaluation

\subsection{Construction of judgment matrix}

According to the relationship between the national defense patent technical indicators to be evaluated, a judgment matrix can be constructed that connects a certain indicator to the next level, which is obtained by comparing pairwise according to a certain ratio scale. The meaning of the scale is shown in Table 2.

Table 2 Correspondence table of scale meaning of judgment matrix

\begin{tabular}{|c|c|c|c|}
\hline $\begin{array}{l}\text { Relative } \\
\text { scale }\end{array}$ & implication & $\begin{array}{l}\text { Relative } \\
\text { scale }\end{array}$ & implication \\
\hline 1 & $\begin{array}{l}\text { Two indicators are equally } \\
\text { important. }\end{array}$ & $2,4,6,8$ & $\begin{array}{l}\text { This represents the intermediate state of the odd value } \\
\text { case. }\end{array}$ \\
\hline 3 & $\begin{array}{l}\text { The former indicator is slightly } \\
\text { more important than the latter. }\end{array}$ & \multirow{4}{*}{ Reciprocal } & \multirow{4}{*}{$\begin{array}{l}\text { If the ratio of importance of indicator } r_{i} \text { to } r_{j} b_{i j} \text {, then } \\
\text { the ratio of importance of indicator } r_{j} r_{j} \text { is } \\
b_{j i}=\frac{1}{b_{i j}}\end{array}$} \\
\hline 5 & $\begin{array}{l}\text { The former indicator is more } \\
\text { important than the latter. }\end{array}$ & & \\
\hline 7 & $\begin{array}{l}\text { The former indicator is obviously } \\
\text { more important than the latter. }\end{array}$ & & \\
\hline 9 & $\begin{array}{l}\text { The former indicator is extremely } \\
\text { important than the latter. }\end{array}$ & & \\
\hline
\end{tabular}

\subsection{Calculation of relative weight}

The relative weights of the technical indicators for evaluating the value of defense patents are shown in the following table after comparison and assignment by experts.

Table 3 The relative weight table I of national defense patent technical indicators by the analytic hierarchy process

\begin{tabular}{|c|c|c|c|c|}
\hline Technical indicators & Technical field & Technical features & $\begin{array}{c}\text { Technology } \\
\text { application }\end{array}$ & $\begin{array}{c}\text { Weighting } \\
\text { coefficient }\end{array}$ \\
\hline Technical field & 1 & $1 / 5$ & 3 & 0.204 \\
\hline Technical features & 5 & 1 & 7 & 0.717 \\
\hline Technology application & $1 / 3$ & $1 / 7$ & 1 & 0.079 \\
\hline
\end{tabular}

Table 4 The relative weight table II of national defense patent technical indicators by the analytic hierarchy process

\begin{tabular}{|c|c|c|c|c|c|}
\hline $\begin{array}{c}\text { Technical field } \\
\text { indicators }\end{array}$ & $\begin{array}{c}\text { Technology } \\
\text { development } \\
\text { stage }\end{array}$ & $\begin{array}{c}\text { Technology } \\
\text { implementation } \\
\text { difficulty }\end{array}$ & $\begin{array}{c}\text { Technology } \\
\text { competition } \\
\text { intensity }\end{array}$ & $\begin{array}{c}\text { Related } \\
\text { technical fields } \\
\text { status }\end{array}$ & $\begin{array}{c}\text { Weighting } \\
\text { coefficient }\end{array}$ \\
\hline $\begin{array}{c}\text { Technology development } \\
\text { stage }\end{array}$ & 1 & 3 & $1 / 7$ & 7 & 0.271 \\
\hline $\begin{array}{c}\text { Technology } \\
\text { implementation difficulty }\end{array}$ & $1 / 3$ & 1 & $1 / 5$ & 5 & 0.159 \\
\hline
\end{tabular}




\begin{tabular}{|c|c|c|c|c|c|}
\hline $\begin{array}{c}\text { Technology competition } \\
\text { intensity }\end{array}$ & 7 & 5 & 1 & 9 & 0.535 \\
\hline $\begin{array}{c}\text { Related technical fields } \\
\text { status }\end{array}$ & $1 / 7$ & $1 / 5$ & $1 / 9$ & 1 & 0.035 \\
\hline
\end{tabular}

Table 5 The relative weight table III of national defense patent technical indicators by the analytic hierarchy process

\begin{tabular}{|c|c|c|c|c|}
\hline $\begin{array}{c}\text { Technical features } \\
\text { indicators }\end{array}$ & $\begin{array}{c}\text { Technology } \\
\text { leadership level }\end{array}$ & $\begin{array}{c}\text { Technical defense } \\
\text { capability }\end{array}$ & $\begin{array}{c}\text { Technological } \\
\text { innovation degree }\end{array}$ & $\begin{array}{c}\text { Weighting } \\
\text { coefficient }\end{array}$ \\
\hline $\begin{array}{c}\text { Technology leadership } \\
\text { level }\end{array}$ & 1 & 5 & 7 & 0.717 \\
\hline $\begin{array}{c}\text { Technical defense } \\
\text { capability }\end{array}$ & $1 / 5$ & 1 & 3 & 0.204 \\
\hline $\begin{array}{c}\text { Technological } \\
\text { innovation degree }\end{array}$ & $1 / 7$ & $1 / 3$ & 1 & 0.079 \\
\hline
\end{tabular}

Table 6 The relative weight table IV of national defense patent technical indicators by the analytic hierarchy process

\begin{tabular}{|c|c|c|c|c|c|}
\hline $\begin{array}{c}\text { Technology application } \\
\text { indicators }\end{array}$ & $\begin{array}{c}\text { Technology } \\
\text { maturity level }\end{array}$ & $\begin{array}{c}\text { Technical } \\
\text { application } \\
\text { scope }\end{array}$ & $\begin{array}{c}\text { Technical } \\
\text { application } \\
\text { conditions }\end{array}$ & $\begin{array}{c}\text { Complementar } \\
\text { y degree of } \\
\text { related }\end{array}$ & $\begin{array}{c}\text { Weighting } \\
\text { coefficient }\end{array}$ \\
\hline $\begin{array}{c}\text { Technology maturity } \\
\text { level }\end{array}$ & 1 & 5 & 5 & 9 & 0.557 \\
\hline $\begin{array}{c}\text { Technical application } \\
\text { scope }\end{array}$ & $1 / 5$ & 1 & 1 & 5 & 0.200 \\
\hline $\begin{array}{c}\text { Technical application } \\
\text { conditions }\end{array}$ & $1 / 5$ & 1 & 1 & 5 & 0.200 \\
\hline $\begin{array}{c}\text { Complementary degree of } \\
\text { related technologies }\end{array}$ & $1 / 9$ & $1 / 5$ & $1 / 5$ & 1 & 0.043 \\
\hline
\end{tabular}

\subsection{Consistency check}

It can be seen that Table 3 is a third-order matrix, with its maximum eigenvalue $\lambda_{\max }=3.073$, consistency index C.I. $=\left(\lambda_{\max }-3\right) /(3-1)=0.0365$, average random consistency index $R . I \cdot=0.52$, consistency ratio C.R. $=$ C.I. $/ R . I .=0.0702<0.1$, so the consistency test

Table 7 The total weight table of national defense patent technical indicators by the analytic hierarchy process

\begin{tabular}{|c|c|c|c|}
\hline $\begin{array}{c}\text { Underlying technical } \\
\text { indicators }\end{array}$ & Total weight coefficient & $\begin{array}{c}\text { Underlying technical } \\
\text { indicators }\end{array}$ & Total weight coefficient \\
\hline $\begin{array}{c}\text { Technology development } \\
\text { stage }\end{array}$ & $0.271 \times 0.204=0.0553$ & Technological innovation degree & $0.079 \times 0.717=0.0566$ \\
\hline $\begin{array}{c}\text { Technology } \\
\text { implementation difficulty }\end{array}$ & $0.159 \times 0.204=0.0324$ & Technology maturity level & $0.557 \times 0.079=0.0440$ \\
\hline $\begin{array}{c}\text { Technology competition } \\
\text { intensity }\end{array}$ & $0.535 \times 0.204=0.1091$ & Technical application scope & $0.200 \times 0.079=0.0158$ \\
\hline $\begin{array}{c}\text { Related technical fields } \\
\text { status }\end{array}$ & $0.035 \times 0.204=0.0072$ & Technical application conditions & $0.200 \times 0.079=0.0158$ \\
\hline $\begin{array}{c}\text { Technology leadership } \\
\text { level }\end{array}$ & $0.717 \times 0.717=0.5141$ & $\begin{array}{c}\text { Complementary degree of } \\
\text { related technologies }\end{array}$ & $0.043 \times 0.079=0.0034$ \\
\hline $\begin{array}{c}\text { Technical defense } \\
\text { capability }\end{array}$ & $0.204 \times 0.717=0.1463$ & & \\
\hline
\end{tabular}

\section{CONCLUSION}

The construction of the index system is the basis for the evaluation of the value of national defense patents [6]. The index characteristics such as the integrity, relevance and operability directly affect the accuracy and credibility of the national defense patent value evaluation and pricing. After the establishment of a relatively perfect index system, how to determine the weight of each indicator according to the specific characteristics of national defense patents is important is passed. In the same way, table 4 , table 5 and table 6 can also pass the consistency test in the same way.

\subsection{Overall index weight fixing}

Finally, the total weight of each indicator relative to the technical indicators of the target layer can be determined, as shown in Table 7 below. to the effective coordination of interests among the subjects of national defense patents. If there is no relatively perfect index system, national defense patent cannot be evaluated objectively. The national defense patent value evaluation index system constructed in this article and the use of analytic hierarchy process to determine the weights of related indicators only provide an academic path for national defense patent value evaluation. How to accurately evaluate the value of a certain national defense patent based on the actual 
situation requires more in-depth and systematic research.

\section{REFERENCES}

[1] Huang Qing, et al, Patent Evaluation Index System (1)- Design and Construction of Patent Evaluation Index System [J], Intellectual Property, 2004(5), pp. 24-25.

[2] Robert F. Reilly, Robert P. Schweiser, Evaluation of intangible assets [M]. Beijing: Encyclopedia of China Publishing House, 2001, pp.116-121.

[3] Xiong Jianping, Methods and Practice of Intellectual Property Evaluation[N]. China Finance and Economic News, 2008(12), pp.3.

[4] Chang Yu, Liu Xiandong, On Application of AHP and Fuzzy Evaluation[J], Intellectual Property, 2002(9), pp. 125-127.

[5] $\mathrm{Fu} \mathrm{Yu}$, Research on the efficiency of national defense patent property rights system $[\mathrm{M}]$. Beijing: National Defense Industry Press, 2018, pp.40-41.

[6] Yang Xiao, Research on the Governance Structure of Defense Intellectual Property Rights Transaction [D], Changsha: National University of Defense Technology, 2015, pp. 169. 